\title{
The planets and our culture a history and a legacy
}

\author{
Theodore C. Clarke ${ }^{1}$ and Scott J. Bolton ${ }^{2}$ \\ ${ }^{1}$ New Renaissance Productions, \\ Altadena, CA 91001 \\ email: tcclarke@earthlink.net \\ ${ }^{2}$ Artistic Sciences, Inc., \\ San Antonio, Texas 78257 \\ email: sbolton@swri.edu
}

\begin{abstract}
This manuscript relates the great literature, great art and the vast starry vault of heaven. It relates the myths of gods and heroes for whom the planets and the Medicean moons of Jupiter are named. The myths are illustrated by great art works of the Renaissance, Baroque and Rococo periods which reveal poignant moments in the myths. The manuscript identifies constellations spun off of these myths. In addition to the images of great art are associated images of the moons and planets brought to us by spacecraft in our new age of exploration, the New Renaissance, in which we find ourselves deeply immersed.
\end{abstract}

Keywords. mythology; paintings; constellations; planets; moons; space exploration

\section{Introduction}

Since the beginning of human history man has sought in the vastness of infinite space a reflection and an understanding of the vastness of his own inner being. He has always identified with the celestial spheres. It was surely so for our ancestors in the Euphrates Valley over 5,000 years ago. There, at that time, thought that would shape our civilization was present about the land. To the east, near the meeting of the Tigris and Euphrates rivers was the site of biblical Eden and the biblical origins of man. To the north was Akkad, site of the origins of the star worship and mythology that would reach its zenith with the Greeks. To the west was Babylonia, site of the origins of astronomy. To the south was Ur, birthplace of Abraham, spiritual father of the Judeo, Christian, and Islamic religions. The same collective mind that was planting the seeds of these three great monotheistic religions was contemplating the nature of the universe and life, and was seeking answers in the heavens above. That same mind populated the firmament with gods, in a zodiac still used today in modern charts of the heavens, and invented great stories and myths of the deeds of those gods. The planets and many of their moons are named for the Greek and Roman gods.

\section{Origins}

Among the classical Greeks the most accepted account of the beginning of things was that given by the poet Hesiod, a near contemporary of Homer. Hesiod tells us in the "Theogony" that Chaos preceded all things (see Figure 1). Next came into being Earth personified as Gaea, and Love. From Mother Earth proceeded the starry vault of Heaven, personified as Uranus, where the gods would take up their abode. Then, in the heart of creation Love stirred making of things male and female, and bringing them 
together by natural affinity. We know today that this notion of opposites brought together by natural affinity is the basis for the subatomic structure of all matter. Uranus took Gaea to wife, and from their union were born the Titans, the Hecatonchires or hundred handed monsters, and the Cyclopes, all manifestations of violent upheavals on Earth. When Uranus tried to destroy the hundred handed monsters and the Cyclopes, whom he dreaded, Gaea, their mother, plotted with the Titans to strike down the tyranny of Uranus. Saturn, god of Time, stepped forward to take up his mother's cause.

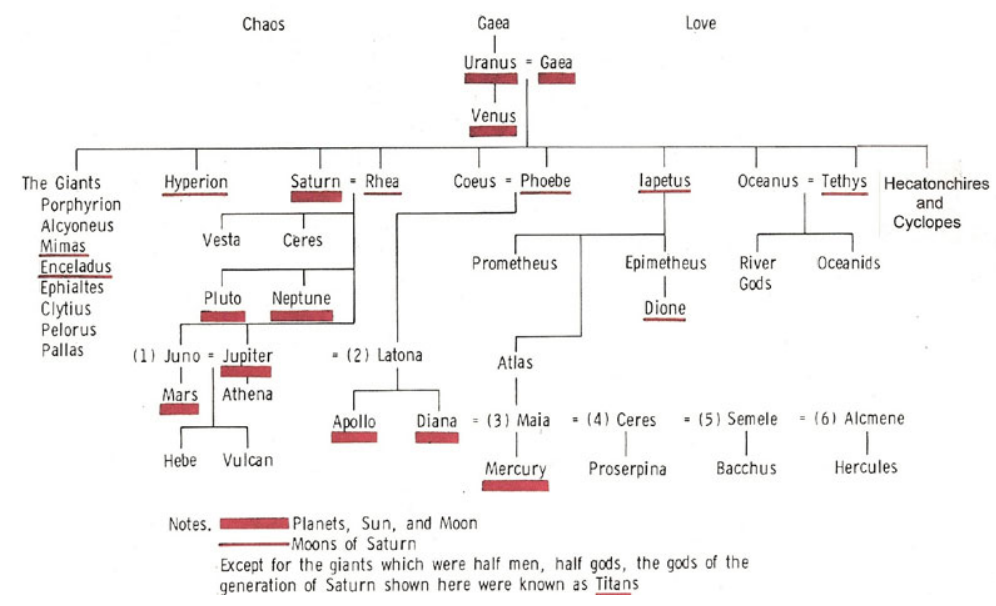

Figure 1. Geneology of the Gods.

Armed with an iron sickle provided him by his mother Gaea, Saturn lay in wait for his sire to come in for the night to overlay Earth. At the right time Saturn fell upon Uranus and grievously wounded him. Saturn thus seized power in Olympus in a bloody cosmic coup. From the bloody member cast into the sea arose Venus (Aphrodite - foam born) and from the blood that fell on Earth arose the Giants. Saturn and the Titans reigned during the golden age of Greek mythology.

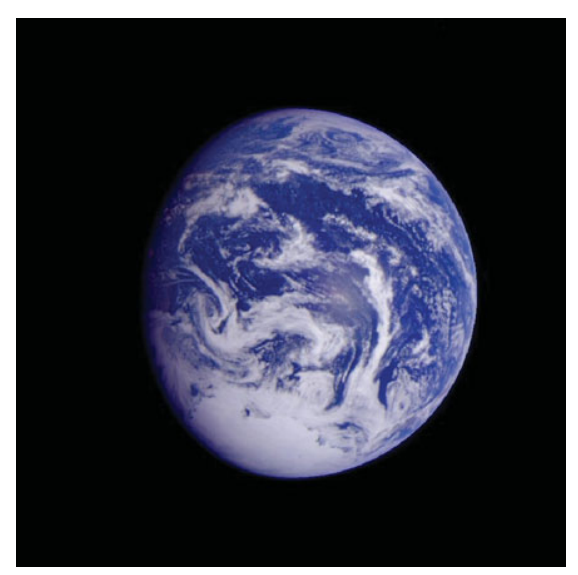

Figure 2. Earth, Galileo 1990.

The Saturn moon Titan was discovered by Christian Huygens in 1655. Huygens was convinced no more celestial bodies would be found orbiting the sun, because Titan (which he named Luna Saturni) was the $12^{\text {th }}$ such body. 12 was such a perfect number, he 


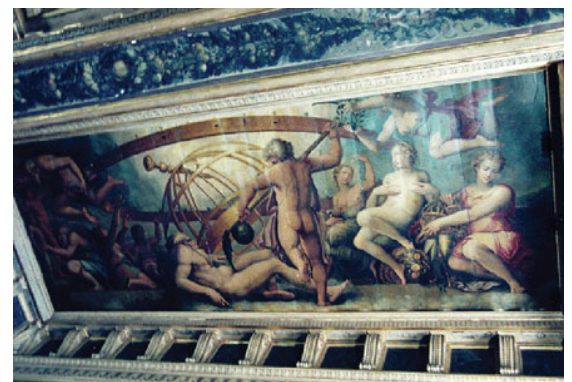

Figure 3. The Mutilation of Uranus, Georgio Vasari and Christofano Gherardi, 16th cent. Italian Renaissance.

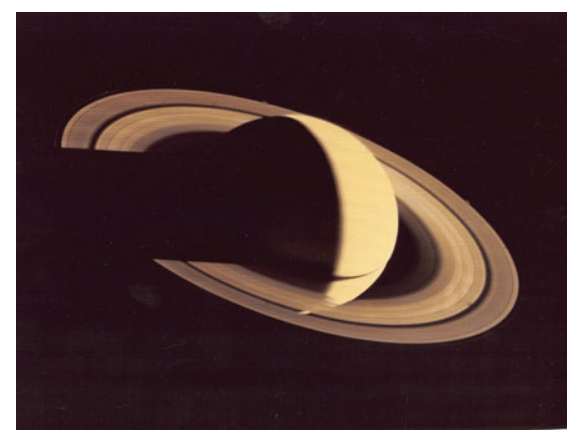

Figure 4. Saturn, Voyager 11980.

reasoned, it could only be the result of divine intent. Were there not 12 tribes of Israel, 12 Disciples of Christ, and 12 signs of the Zodiac? When Giovanni Cassini discovered two more moons of Saturn 16 years later, however, he hastened to point out to his patron Louis XIV that perhaps 14 was more divine than 12. John Herschel in 1858 named the 8 known Saturn moons for the Titans and for the Giants born of the blood that fell to Earth when Saturn castrated Uranus in the cosmic coup.

Saturn, having learned from an oracle that he would be overthrown by one of his own offspring, as he had overthrown his own sire, devoured his children as they were born to prevent this from occurring. Time, the ancients noted, destroyed that which it had created. Rhea, Saturn's sister-goddess-wife and mother of the children, was understandably distressed.

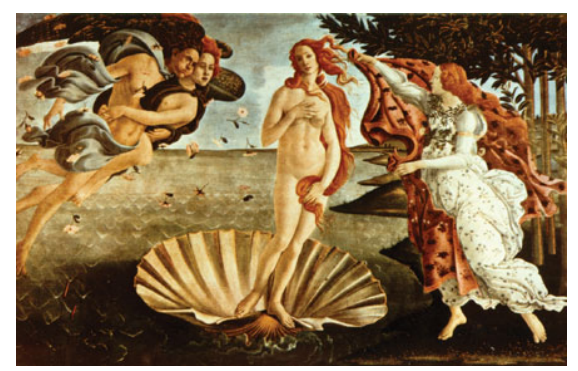

Figure 5. The Birth of Venus, Sandro Botticelli, $16^{\text {th }}$ cent. Italian Renaissance. 


\section{The Reign of Jupiter}

When her $6^{\text {th }}$ child Jupiter was born Rhea passed off a rock wrapped in swaddling clothes in place of Jupiter to the god Saturn and spirited the infant Jupiter off to the island of Crete, where he was cared for by the nymphs Ida and Adrastea, and fed from the milk of the goat Amalthea.

Jupiter quickly grew to manhood (or godhood) and with the help of Gaea fed Saturn an emetic, which caused him to regurgitate his brothers and sisters. They then joined forces in an epic battle with Saturn and the Titans for supremacy of Heaven and Earth. The Jovian gods were triumphant and the defeated Titans were cast into Tartarus, the profound abyss beneath Earth.

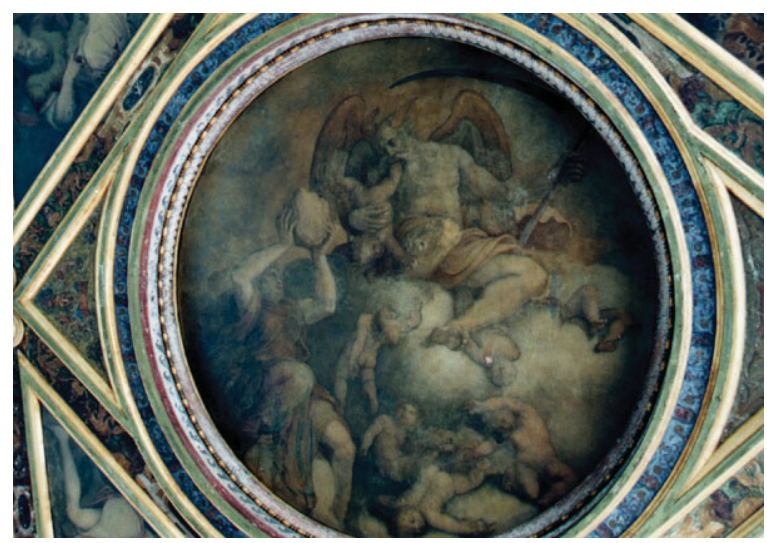

Figure 6. Saturn Devouring His Children, Georgio Vasari, $16^{\text {th }}$ Cent. Italian Renaissance.

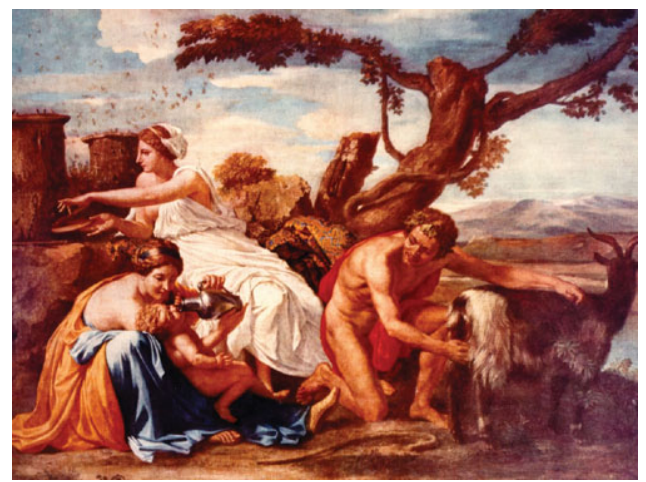

Figure 7. The Nurture of Jupiter, Nicolas Poussin, $17^{\text {th }}$ cent. French Baroque.

After the defeat of the Titans, Jupiter (Zeus) was chosen by all the gods of Olympus to be the supreme ruler of the Heavens, the Earth, and the gods. The Statue of Zeus by Pheidias is one of the Seven Wonders of the Ancient World. The image here is reconstructed from rare coins struck by the Roman Emperor Hadrian in the 2nd cent. A.D. The Stoic Dio Chrysostom, in a speech in 90 A.D., called Pheidias' Zeus "The most beautiful and the dearest to God of all works on Earth, the mere sight of which stills all sorrows." 


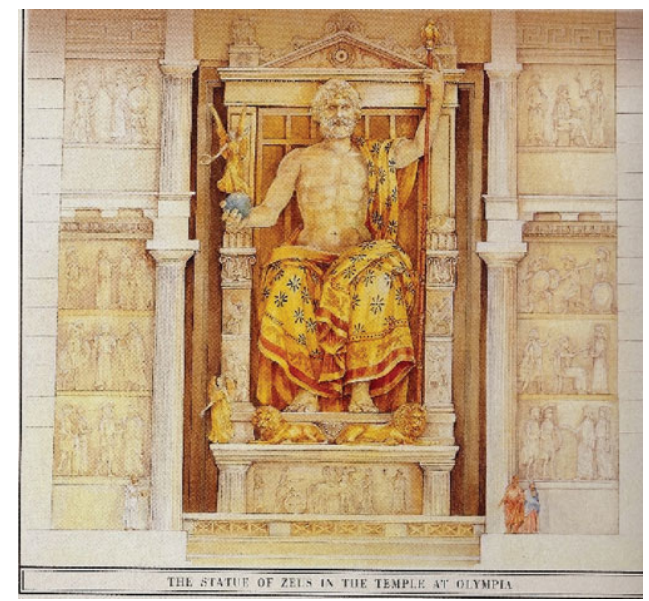

Figure 8. Statue of Zeus, Pheidias, c. 430 B.C.

In time, the Giants, born by Earth from the blood of the mutilated Uranus, rose to challenge the Jovian gods for dominion over Olympus. With the help of Hercules the Jovian gods defeated the Giants. According to legend, in celebration of the victory of the Jovian gods over the Giants, Hercules instituted the first Olympic Games in 776 B.C.

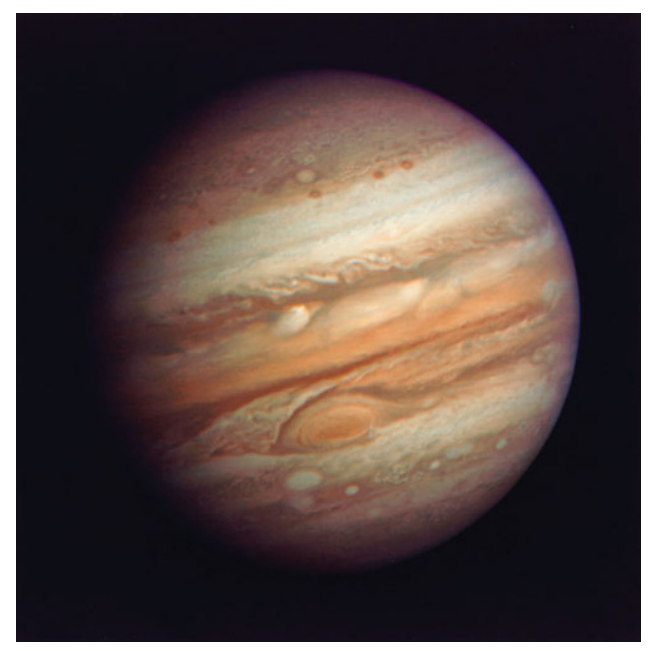

Figure 9. Jupiter, Voyager 1, 1979. 


\section{Myths of Jupiter and those Lovers for Whom the Medicean Moons Are Named}

The link between myths of the ancient past, art of the Renaissance, Baroque and Rococo periods, and space exploration of the present are here represented by the myths of Jupiter and those lovers for whom the Medicean moons are named. Three of the Jovian playmates, Io, Europa, and Callisto were descended from the river god Inachus, son of the Titans Oceanus and Tethys, as seen in the genealogy chart below.

\section{Genealogies of Io, Europa, and Callisto from}

THE RACE OF INACHUS AND ITS BRANCHES

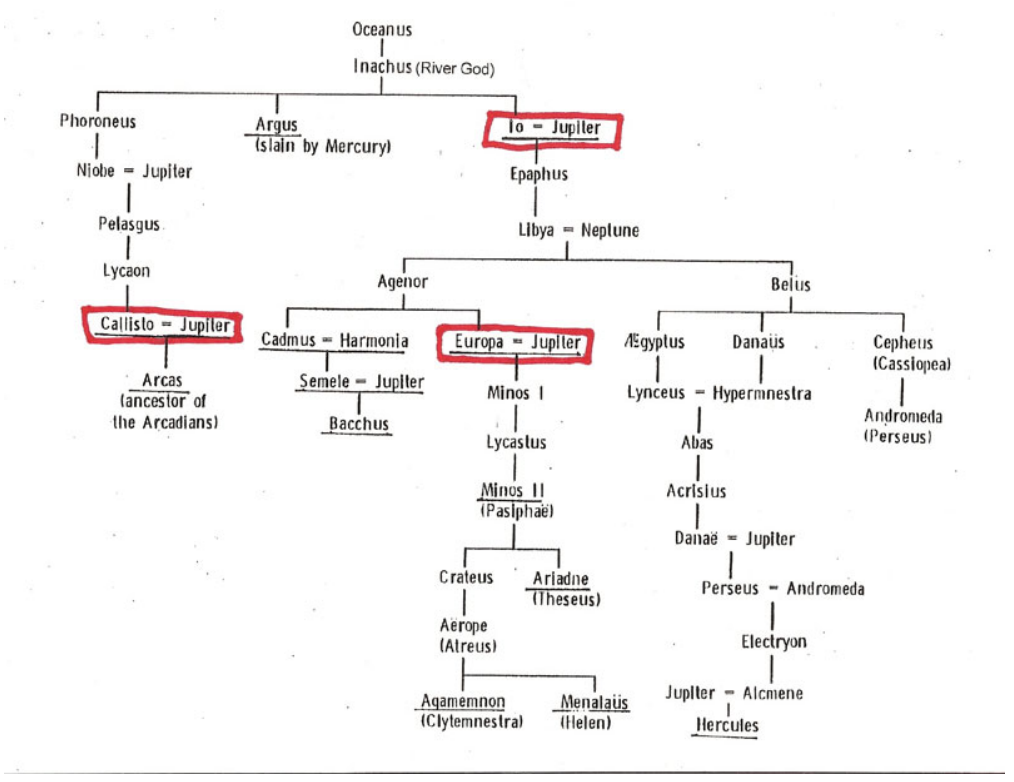

Figure 10. Genealogies of Io, Europa, and Callisto.

\section{The Myth of Jupiter and Io}

Io was a river nymph, daughter of the river god Inachus. One day Jupiter spotted the sweet and innocent Io on the banks of the Inachus River, near where it flows into the Argolic Gulf. As was his want, Jupiter fell in love with the beautiful Io. He came down from Olympus to be with her and spread a cloud over the land to conceal his dalliance from his jealous wife Juno.

In the painting Jupiter and Io Jupiter plants an immortal kiss on the ecstatic cheek of the river nymph Io. Jupiter had visited Io in her dreams and whispered to her as she slept: 


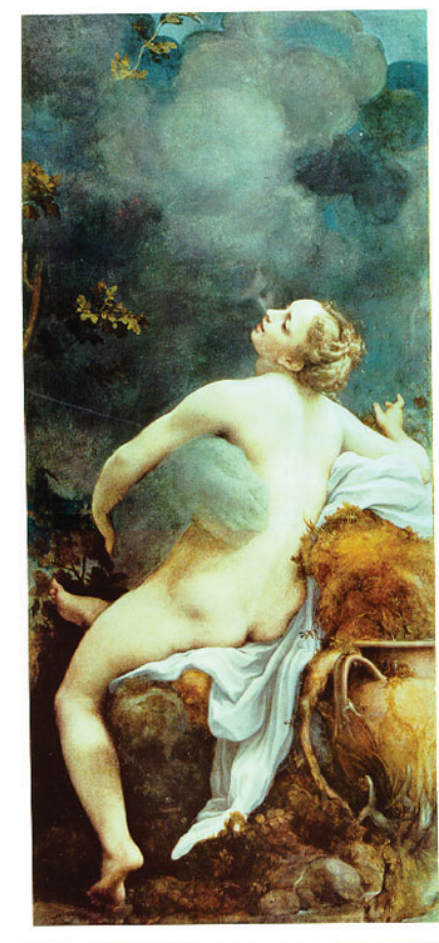

Figure 11. Jupiter and Io, Antonio Allegri da Correggio, $16^{\text {th }}$ cent. Italian Renaissance.

"Now to the meadow land of Lerna, where thy father's pastures lie, And the sleek cattle browse, do thou steal forth Alone, and happly there thy yielding grace May sooth the passion in the Sovereign's eye" Aeschylus, Prometheus Bound

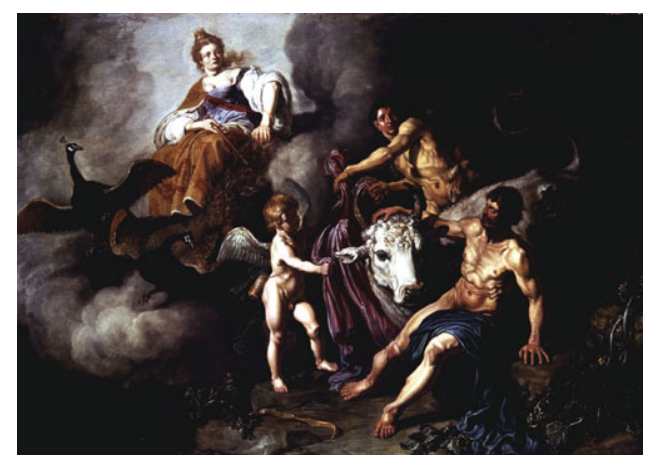

Figure 12. Juno Discovering Jupiter with Io, Pieter Lastman, $17^{\text {th }}$ cent. Dutch artist.

Juno noted the cloud covering all of the Peloponnesus, and noted too that her husband Jupiter was not on his throne on Mt. Olympus. She became suspicious and decided to investigate. In the painting Juno Discovering Jupiter with Io we see Juno mounted on her peacock drawn chariot penetrating the clouds just as Jupiter, sensing her coming, changes Io into a heifer. 
This tale is the basis for the name Juno given to the NASA space mission, which will

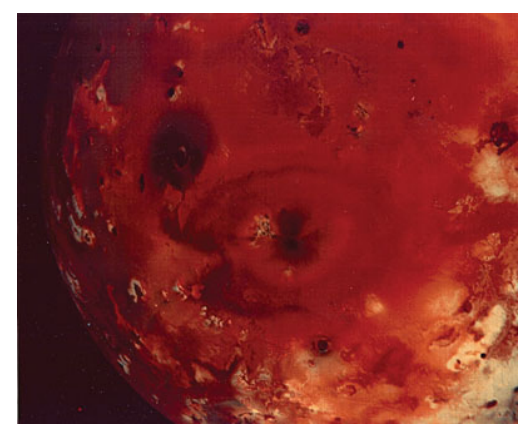

Figure 13. The Medicean Moon Io, Voyager 1, 1979.

be launched to Jupiter in 2011, will penetrate Jupiter's clouds with its instruments, and will learn Jupiter's secrets.

The names of the Ionian Sea and the Bosporus (fording of the ox) also derive from this myth. Note the prominent volcanic feature Loki in the Voyager image of Io, which looks amazingly like the hoof print of a heifer.

\section{The Myth of Jupiter and Europa}

From the myth of Jupiter and Europa comes the names of a major constellation and of a continent. Jupiter caught sight of Europa, the legendary princess of Phoenicia, as she picked flowers by the sea, and was instantly overwhelmed with love for her.

Jupiter took the shape of a bull, meandered over to where Europa played, and knelt by the princess. Europa was enthralled and climbed upon the bull's back and spread garlands of flowers about its neck. At that instant Jupiter the bull leapt into the sea with Europa clinging frantically to his horns, and carried her across the sea to the island of Crete. There he cast off his shape of a bull and tossed it into the heavens as the constellation Taurus.

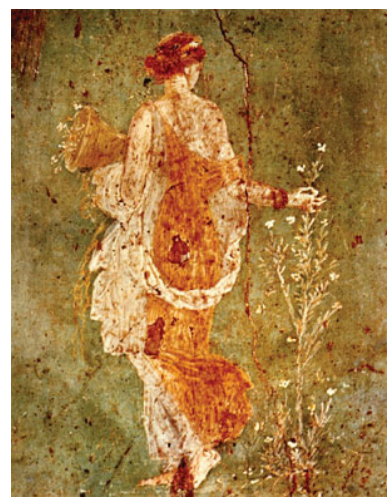

Figure 14. Europa Picking Flowers, Fresco found in the ruins of Pompeii, 40 A.D., copy after Apelles, c. 430 B.C..

Legend has it that the continent of Europe was named for this event. Charlemagne, who conquered most of what we know today as Europe, was familiar with this legend, and some say it was he who officially gave the continent its name. According to the 


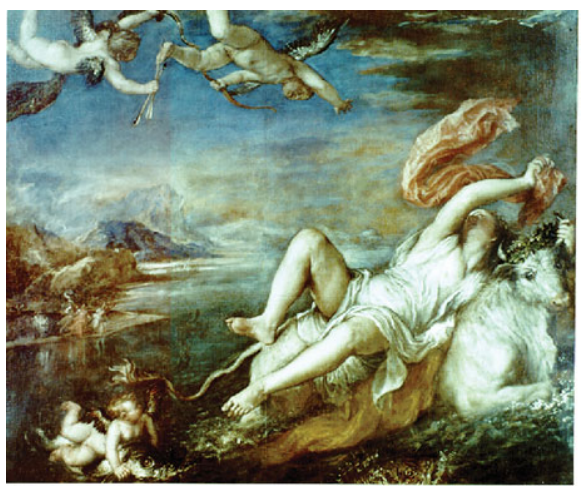

Figure 15. The Abduction of Europa, Titian, $16^{\text {th }}$ cent. Italian Renaissance.

myth Europa bore Jupiter 3 sons, among them Minos, legendary ancestor of the Minoan civilization, first of the great Greek civilizations.

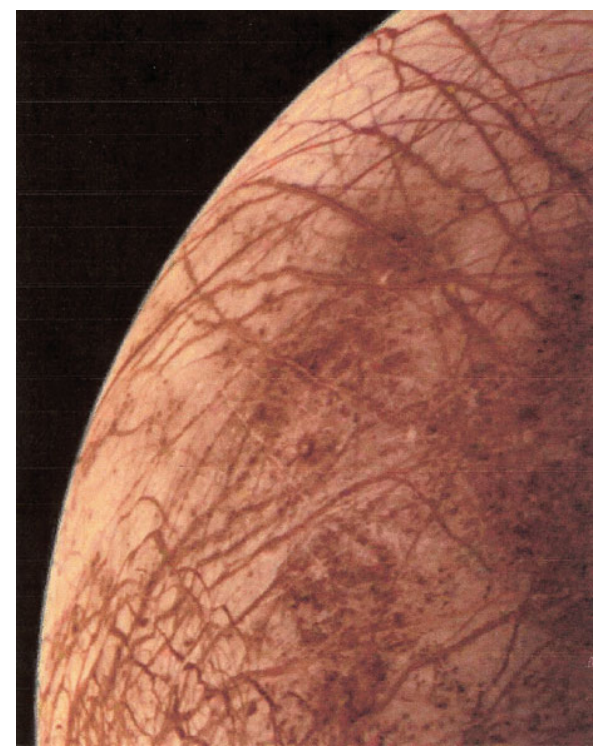

Figure 16. The Medicean Moon Europa, Voyager 1, 1979.

\section{The Myth of Jupiter and Ganymede}

According to the myth, one day as Jupiter was surveying his domain he spotted the boy Ganymede tending a flock of sheep on the slopes of Mt. Ida near Troy. Jupiter suddenly felt a profound passion for the boy, changed his shape into that of an eagle, swooped down and snatched the boy up and carried him off to Mt. Olympus to serve as cup bearer of the gods. However, cup bearer, or water bearer, was a position already held by the young goddess Hebe, daughter of Juno and Jupiter. In the painting Ganymede and Hebe Vying to Serve Jupiter we see Ganymede, with boyish facial hair, and Hebe, with adolescent breasts, vying to serve Jupiter while Juno stands nearby. Also shown, at the feet of Jupiter, is the goat Amalthea, whose milk nourished him as an infant. In the background is a scene depicting the abduction of Europa. Jupiter, in the shape of 


\section{THE ROYAL FAMILY OF TROY}

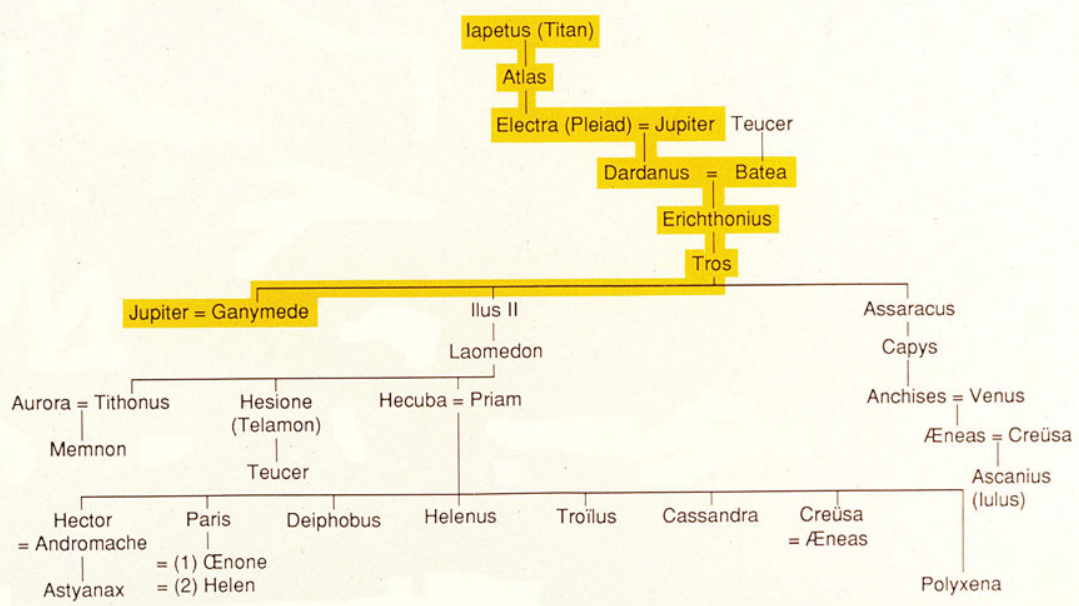

Figure 17. Genealogy of Ganymede.

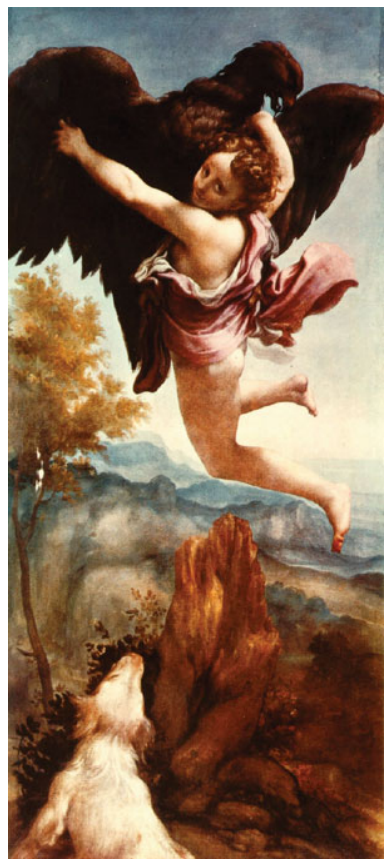

Figure 18. The Abduction of Ganymede, Correggio, $16^{\text {th }}$ cent. Italian Renaissance.

a bull, is plunging through the sea, with the pink clad Europa in much distress. Two constellations celebrate the myth of Jupiter and Ganymede: Aquarius the Water Bearer and Aquila the Eagle. 


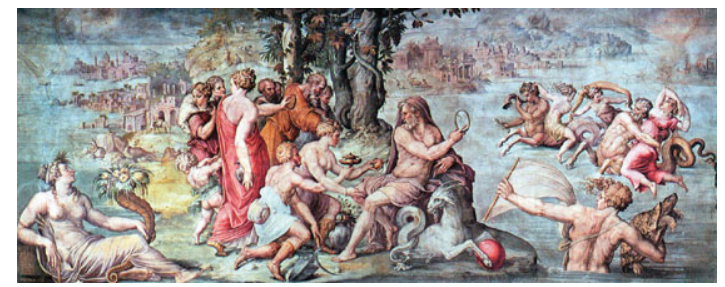

Figure 19. Ganymede and Hebe Vying to Serve Jupiter, Cristofano Gherardi, c. 1565.

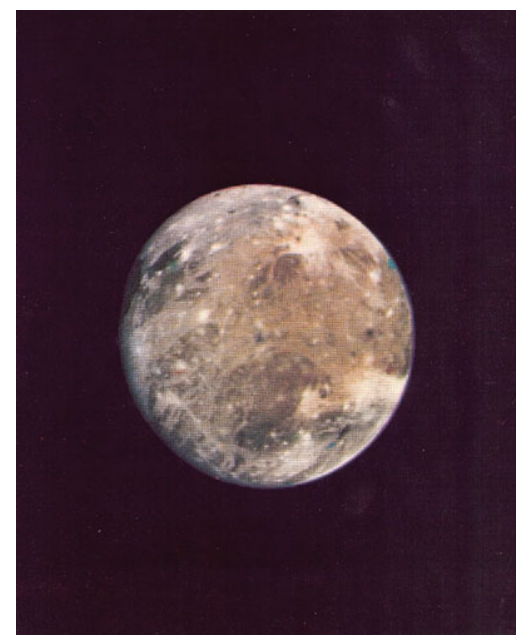

Figure 20. The Medicean Moon Ganymede, Voyager 1, 1979.

\section{The Myth of Jupiter and Callisto}

Callisto was the favored companion of the virgin goddess Diana. Diana had warned her companions that if they wished to remain in her company, they must remain chaste. Callisto had accordingly vowed chastity. One day Jupiter saw the beautiful and chaste Callisto lying in the woods, waiting for Diana. He was aware of Diana's cautionary words to her companions, and was aware too of the special relationship Callisto had with Diana.

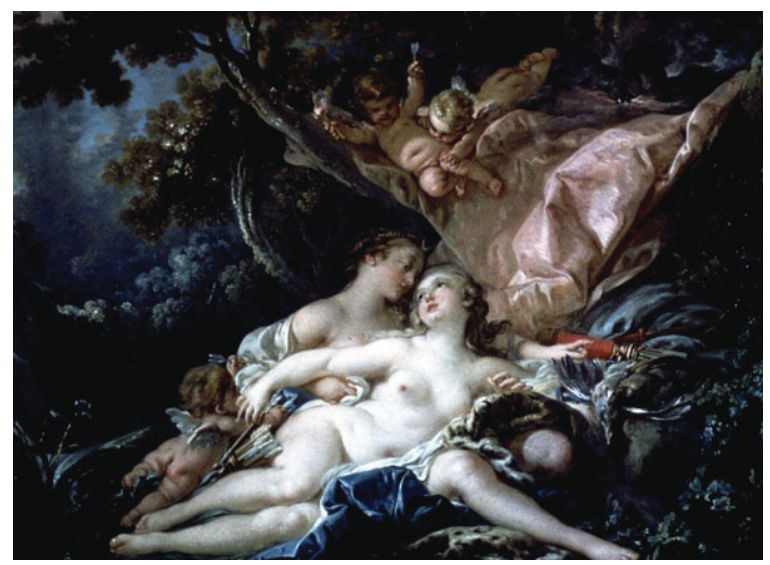

Figure 21. Jupiter in the Guise of Diana and the Nymph Callisto, Francois Boucher, $18^{t h}$ Cent. Rococo. 


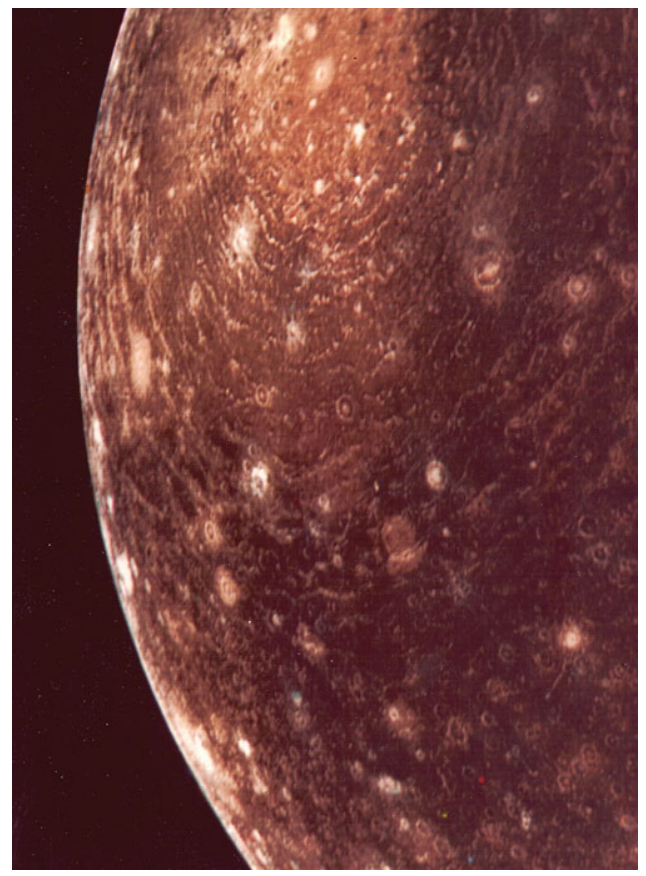

Figure 22. The Medicean Moon Callisto, Voyager 1, 1979.

So, in an inspired stratagem, Jupiter changed his shape into that of Diana, and went into the woods to where Callisto lay.

In Boucher's painting above, we see Jupiter as Diana, embracing the innocent Callisto. He whispers words of love to her:

"You are Callisto!

I behold in your eyes

The dawn of creation;

I behold in your smile

The innocence of surrender;

I behold the joy that you are,

And love is born in my breast

As stars are born in the arms of the galaxies,

And galaxies in the bosom of the Universe.

Fair Callisto,

I love you."

Callisto succumbs to Jupiter's words of love, and in their passionate embrace she conceives a child. Soon enough Callisto's condition becomes obvious and Diana forces her out of her company for having violated her strict rules of behavior. In time Callisto gives birth to a child, whom she names Arcas. Juno is outraged at this evidence of Jupiter's infidelity and changes Callisto into a bear. Callisto the bear is frightened and runs away into the woods, not to see her son for many years.

One day, when Arcas is a handsome and sturdy young man, he goes into these very woods to hunt, not realizing that his mother the bear resides there. Callisto sees her son Arcas, whom she hasn't seen for many years, and, forgetting she is a bear, rushes to embrace him. Arcas sees only a bear rushing down on him. He pulls out his bow and 
arrow and lets fly an arrow to the mark. At the last moment, just before the arrow strikes, Jupiter snatches up Callisto and her son Arcas and casts them into the heavens as the constellations Ursa Major and Ursa Minor, the big and little bears, the most recognizable parts of these constellations being the big and little dippers.

\section{Conclusion}

We have related myths of the great classics of Greek literature, illustrated them with masterworks of Renaissance, Baroque and Rococo art, identified the constellations, bodies of water and the continent that spun off these myths, and leapt into the present with images taken by our mighty spacecraft of the planets and Medicean moons named for the mythological characters of the myths related.

\section{Epilogue}

Epilogue is prologue. The history and legacy of one era becomes the starting point for the next. In this paper we have linked the past to the present and ride the crest of the New Renaissance into the future. From the dawn of time we have asked: Who am I? Where do I come from? We asked in the marshy Edens of Sumer, again in the glory that was Greece, again in the grandeur of the Renaissance, and again today. Today we are immersed in a New Renaissance and once again communications, the arts, mathematics and science are exploding in unison. The binary code, the internet, and space exploration are the masterworks of this new age.

\section{Figures:}

Fig. 1: Genealogy of the Gods, adapted from Table A, The Great Gods of Olympus, in Gayley's Mythology

Fig. 2: Planet Earth, image by Galileo taken during the first Earth encounter, 1990

Fig. 3: The Mutilation of Uranus, Georgio Vasari and Christofano Gherardi, 1560, Palazzo Vecchio, Florence, Italy

Fig. 4: Planet Saturn, image by Voyager 1 taken during the Saturn encounter, 1980

Fig. 5: The Birth of Venus, Sandro Botticelli, 1600, Uffizi Gallery, Florence, Italy

Fig. 6: Saturn Devouring His Children, Georgio Vasari, c. 1560, Palazzo Vecchio, Florence, Italy

Fig. 7: The Nurture of Jupiter, Nicolas Poussin, 1640, Dahlen State Museum, Berlin, Germany

Fig. 8: The Statue of Zeus, picture in Mythology, by Lady Hestia Evans, edited by Dugald Asteer, Candlewick Press, Doverville, MA, 2007

Fig. 9: Planet Jupiter, image by Voyager 1 taken during the Jupiter encounter, 1979

Fig. 10: Genealogies of Io, Europa, and Callisto, adapted from Table D, The Race of Inachus and its Branches, in Gayley's Mythology

Fig. 11: Jupiter and Io, Antonio Allegri da Correggio, c. 1530, Kunsthistorisches Museum, Vienna, Austria

Fig. 12: Juno Discovering Jupiter and Io, Pieter Lastman, 1618, The National Gallery, London, England

Fig. 13: The Medicean Moon Io, image by Voyager 1 taken during the Jupiter encounter, 1979

Fig. 14: Europa Picking Flowers, fresco found in the ruins of Pompeii, c 40 A.D., copy after Apelles, c. 430 B.C. 
Fig. 15: The Abduction of Europa, Titian, 1562, Isabella Stewart Gardner Museum, Boston, MA

Fig. 16: The Medicean Moon Europa, image by Voyager 1 taken during the Jupiter encounter, 1979

Fig. 17: Genealogy of Ganymede, adapted from Table O(5), The Royal Family of Troy, in Gayley's Mythology

Fig. 18: The Abduction of Ganymede, Correggio, 1532, Kunsthistorisches Museum, Vienna, Austria

Fig. 19: Ganymede and Hebe Vying to Serve Jupiter, Cristofano Gherardi, c. 1565, Palazzo Vecchio, Florence, Italy

Fig. 20: The Medicean Moon Ganymede, image by Voyager 1 taken during the Jupiter encounter, 1979

Fig. 21: Jupiter in the Guise of Diana and the Nymph Callisto, Francois Boucher, 1759, Nelson Gallery - Atkins Museum, Kansas, MO

Fig. 22: The Medicean Moon Callisto, image by Voyager 1 taken during the Jupiter encounter, 1979

\section{References}

Aeschylus 1938, Prometheus Bound The Complete Greek Drama, edited by Whitney J. Oates and Eugene O'Neill, Jr., Random House, New York

Gayley, C. M. 1939, The Classic Myths in English Literature and in Art, Ginn and Company, Boston

1893, The Iliad of Homer, tr. by Andrew Lang, Walter Leaf, and Ernest Myers, MacMillan and Co., New York

1955, The Metamorphoses of Ovid, tr. by Mary M. Innes, Penguin Books, Baltimore

1950, The Odyssey of Homer, tr. by S. H. Butcher and A. Lang, Random House, The Modern Library, New York

1977, The Theogony of Hesiod, Hesiod, The Homeric Hymns and Homerica, tr. by Hugh G. Evelyn-White, Harvard University Press, Cambridge, MA

Clarke, T. C., 1979, A Love Poem from Jupiter to Callisto Science of Mind Magazine, August 1979 